\title{
The effect of soil compost treatments on potato cyst nematodes Globodera rostochiensis and Globodera pallida
}

\author{
M. RENČO ${ }^{1}$, N. SASANELLI ${ }^{2}$, P. KOVÁČIK ${ }^{3}$
}

\begin{abstract}
${ }^{1}$ Institute of Parasitology, Department of Plant Nematology, Slovak Academy of Sciences, Hlinkova 3, 040 01, Košice, Slovak Republic, E-mail: renco@saske.sk; ${ }^{2}$ Institute for Plant Protection, Section of Nematology, Italian National Council of Researches, Via G. Amendola 122/D, 70126 Bari, Italy, E-mail: n.sasanelli@ba.ipp.cnr.it; ${ }^{3}$ Department of Agrochemistry and Plant Nutrition, Faculty of Agrobiology and Food Resources, Slovak Agricultural University in Nitra, Trieda A. Hlinku 2, 94901 Nitra, Slovakia, E-mail: Peter.Kovacik@uniag.sk
\end{abstract}

\begin{abstract}
Summary
A pot experiment on potato was carried out to verify the nematicidal effect of four composts of different origin $(\mathrm{C} 1$ : $70 \%$ horse manure $+15 \%$ sugar beet pomace $+5 \%$ poultry manure $+10 \%$ grape pomace; $\mathrm{C} 2: 100 \%$ pig manure decomposed by juveniles of Musca domestica; C3: $100 \%$ vermicompost from medical plants wastes; C4: $100 \%$ vermicompost from cattle manure) on the potato cyst nematodes G. rostochiensis (Ro1) and G. pallida $(\mathrm{Pa} 2$ and Pa3). Composts at different rates (1.0, 2.5 and $5.0 \%$ $\mathrm{w} / \mathrm{w})$ were mixed with the nematode infested soils. Pots with unamended soils were used as control. Pots (4 1) were arranged in a glasshouse according to a randomized block design with four replications per each treatment. A significant reduction in number of cysts, eggs and juveniles/cyst and eggs and juveniles/g soil was observed in each compost in comparison to unamended soil. The suppressive nematode effect increased according to the compost $\mathrm{NH}_{4}{ }^{+}$content and compost rate.
\end{abstract}

Keywords: potato cyst nematode; Globodera rostochiensis; Globodera pallida; compost; soil organic amendments; pathotypes

\section{Introduction}

According to the recent European Legislations (Reg. CE 396/2005; 1095/2007; 33 and 299/2008 and 1107/2009) which have deeply restricted and revised the use of pesticides on agricultural crops, the increasing attention to the environment safety and to human and animal health is stimulating investigation to find new alternative control strategies that are environmentally sound and economically convenient at the same time. Therefore, research on low environmental impact alternatives to chemicals has received a strong impulse and considered a wide range of options including agronomic and physical methods (green manures, crop rotations, soil amendments, the use of re- sistant cultivars and arbuscular mycorrhyzal fungi, soil solarization and steam), the use of natural products from plants and biological control agents (Gamliel et al., 2000; Vannacci \& Gullino, 2000; Sasanelli et al., 2002, 2008, 2009; D'Addabbo \& Sasanelli, 2003; Nico et al., 2004; Ogbenin, 2004; Atungwu, 2005; D'Addabbo et al., 2005; Castillo et al., 2006).

Among these alternative control strategies, the incorporation into the soil of organic amendments it is particularly interesting because of their low cost and a more general positive agronomic effect on plant growth and physical, chemical and biological properties of the soils (Davey, 1996). Moreover, it can allow the management of large amounts of wastes generated by urban settlements and agro-industrial processes, after their transformation by composting process, and in addition, it can improve plant resistance and plant protection by stimulating root development by recycling plant nutritive elements (De Bertoldi, 2008). Many organic material wastes represent an important resource of nitrogen, phosphorous, calcium and other elements as zinc, copper and magnesium essential to plant growth (Tester, 1990).

There are sufficient data to indicate that organic materials reduce disease incidence caused by a wide range of plant pests including bacteria, soil-borne pathogens and phytoparasitic nematodes species (D'Addabbo et al., 1997; 2000; Abawi \& Widmer, 2000; Bailey \& Lazarovits, 2003; Renčo et al. 2007, 2009, 2010; Hu \& Qi, 2010). In particular, the suppressive effect of soil amendments, with a wide range of composted waste materials, on plant parasitic nematodes was largely and frequently documented, although an inconsistent nematode control or variable effects were also described in literature (Szczech et al., 1993; McSorley \& Gallagher, 1995; McSorley et al., 1997; Akhtar \& Malik, 2000; Zhao et al., 2003).

Therefore, the nematicidal effect of compost amendments is scarcely predictable as depending on the starting raw 
Table 1. Chemical analysis of used composts

\begin{tabular}{c|c|c|c|c|c|c}
\hline Compost & $\begin{array}{c}\mathbf{p H}^{*} \\
\mathbf{( 1 : 1 0 )} \mathbf{H}_{\mathbf{2}} \mathbf{O}\end{array}$ & $\begin{array}{c}\mathbf{D M} \\
\mathbf{( \% )}\end{array}$ & $\begin{array}{c}\mathbf{N}_{\mathbf{t}} \\
\mathbf{( m g / k g ~ D M ) ~}\end{array}$ & $\begin{array}{c}\mathbf{N}-\mathbf{N H}_{\mathbf{4}}{ }^{+} \\
\mathbf{( m g / k g ~ D M ) ~}\end{array}$ & $\begin{array}{c}\mathbf{C}_{\mathbf{L}} \\
\mathbf{( m g / k g ~ D M})\end{array}$ & $\mathbf{C : N}$ \\
\hline $\mathbf{C 1}$ & $8.4^{* *}$ & 45.50 & 14,221 & 436 & 18,450 & $12.4: 1$ \\
$\mathbf{C 2}$ & 7.9 & 87.83 & 24,465 & 1,260 & 16,890 & $16.2: 1$ \\
$\mathbf{C 3}$ & 7.7 & 59.68 & 7,956 & 112 & 9,045 & $14.4: 1$ \\
$\mathbf{C 4}$ & 7.0 & 69.00 & 17,731 & 168 & 27,000 & $9.2: 1$ \\
\hline
\end{tabular}

$\mathrm{DM}$ - dry matter, $\mathrm{N}$ - total nitrogen, $\mathrm{NH}_{4}^{+}$- ammonium ions, $\mathrm{C}_{\mathrm{L}}$ - available carbon;

${ }^{*} \mathrm{pH}$ value in aqueous extract, which was obtained by mechanically shaking the samples for

1 hour with double distilled water at a solid: water ratio of 1:10 (dry weight $\mathrm{x}$ volume $\left.{ }^{-1}\right)$;

**Each value was an average of four replictions.

materials, the type of composting process, the maturity of the final product incorporated into the soil, nematode species present and season of application (Rodríguez-Kábana et al., 1987; Rivera \& Aballay, 2008). Many mechanisms can be involved in this suppressive effect such as decomposition of the compost into the soil and ammonia production, stimulation of soil microbial biomass and release of biocidal substances, which have nematicide activity (McSorley \& Gallaher, 1996; Oka \& Yermiyahu, 2002). The nematicidal activity, therefore, should be specifically assessed for each compost. The study presented in this paper was aimed to a comparative evaluation of the nematicidal potential of four new composts, based on horse, poultry, pig and cattle manures, sugar beet pomace, grapevine and medical plant wastes, largely available in Slovak Republic, against different pathotypes of the potato cyst nematodes Globodera rostochiensis (Woll.) Behrens (Ro1) and G. pallida (Stone) Behrens ( $\mathrm{Pa} 2$ and $\mathrm{Pa} 3$ ) on potato (Solanum tuberosum L.). cv. Désirée in potting mixtures, in glasshouse condition.

\section{Material and methods}

Four different composts $\left(\mathrm{C}_{1}: 70 \%\right.$ horse manure $+15 \%$ sugar beet pomace $+5 \%$ poultry manure $+10 \%$ grape pomace; $\mathrm{C}_{2}$ : $100 \%$ pig manure decomposed by juveniles of Musca domestica; $\mathrm{C}_{3}: 100 \%$ vermicompost from medical plants waste; $\mathrm{C}_{4}: 100 \%$ vermicompost from cattle manure) were added and mixed with steam sterilised sandy-loamy soil $\left(80^{\circ} \mathrm{C}\right.$ for $\left.30 \mathrm{~min}\right)$ at rates of $1,2.5$ and 5 $\% \mathrm{w} / \mathrm{w}$ (dry weight). Each mixture was then used to fill plastic pots $(20 \mathrm{~cm}$ diameter) with $4000 \mathrm{~g}$ of soil. Pots with unamended soil were used as control. One month later, one hundred cysts of $G$. rostochiensis, previously identified as pathotype Ro1, and one hundred cysts of $G$. pallida of the pathotypes $\mathrm{Pa} 2$ and $\mathrm{Pa} 3$ were added to each pot (including the control, and a potato tuber (cv. Désirée) was sown at the same time. All pots were arranged in a glasshouse at $20 \pm 3{ }^{\circ} \mathrm{C}$ according to a randomized block design with 4 replications per treatment. During the experiment, potato plants were maintained in the glasshouse randomizing the position of the blocks and at

Table 2. The effect of four composts, at different doses, on the suppression of Globodera rostochiensis, pathotype Ro1

\begin{tabular}{|c|c|c|c|c|c|c|c|c|c|c|}
\hline \multirow[b]{2}{*}{ Compost } & \multirow{2}{*}{$\begin{array}{c}\text { Compost } \\
\text { rate } \\
\% \mathrm{w} / \mathrm{w} \\
\end{array}$} & \multicolumn{9}{|c|}{ Number } \\
\hline & & \multicolumn{3}{|c|}{ Cysts } & \multicolumn{3}{|c|}{$\begin{array}{c}\text { Egg and } \\
\text { Juveniles/cyst }\end{array}$} & \multicolumn{3}{|c|}{$\begin{array}{c}\text { Egg and } \\
\text { Juveniles/g soil }\end{array}$} \\
\hline \multirow{4}{*}{ C1 } & 0 & $437 *$ & $\mathrm{a}^{* *}$ & $\mathrm{~A}$ & 269 & $\mathrm{a}$ & $\mathrm{A}$ & 29.5 & $\mathrm{a}$ & $\mathrm{A}$ \\
\hline & 1.0 & 286 & $\mathrm{~b}$ & B & 211 & $\mathrm{~b}$ & B & 15.2 & $\mathrm{~b}$ & $\mathrm{BC}$ \\
\hline & 2.5 & 261 & $\mathrm{~cd}$ & B & 136 & $\mathrm{c}$ & $\mathrm{C}$ & 8.9 & $\mathrm{c}$ & $\mathrm{CD}$ \\
\hline & 5.0 & 195 & d & $\mathrm{B}$ & 112 & c & $\mathrm{C}$ & 5.5 & $\mathrm{c}$ & D \\
\hline \multirow{4}{*}{$\mathrm{C} 2$} & 0 & 437 & $\mathrm{a}$ & $\mathrm{A}$ & 269 & $\mathrm{a}$ & $\mathrm{A}$ & 29.5 & $\mathrm{a}$ & $\mathrm{A}$ \\
\hline & 1.0 & 152 & b & B & 216 & $\mathrm{~b}$ & B & 8.3 & $\mathrm{~b}$ & B \\
\hline & 2.5 & 114 & $\mathrm{~b}$ & $\mathrm{BC}$ & 182 & $\mathrm{c}$ & $\mathrm{C}$ & 5.2 & $\mathrm{bc}$ & $\mathrm{BC}$ \\
\hline & 5.0 & 44 & $\mathrm{c}$ & $\mathrm{C}$ & 122 & $\mathrm{~d}$ & $\mathrm{D}$ & 1.3 & $\mathrm{c}$ & $\mathrm{C}$ \\
\hline \multirow{4}{*}{ C3 } & 0 & 437 & $\mathrm{a}$ & A & 269 & $\mathrm{a}$ & A & 29.5 & $\mathrm{a}$ & A \\
\hline & 1.0 & 410 & $\mathrm{a}$ & A & 240 & $\mathrm{~b}$ & A & 24.6 & $\mathrm{a}$ & $\mathrm{AB}$ \\
\hline & 2.5 & 365 & $\mathrm{~b}$ & A & 203 & $\mathrm{c}$ & B & 18.4 & $\mathrm{~b}$ & $\mathrm{BC}$ \\
\hline & 5.0 & 352 & $\mathrm{~b}$ & A & 179 & $\mathrm{c}$ & $\mathrm{B}$ & 15.5 & $\mathrm{~b}$ & $\mathrm{C}$ \\
\hline \multirow{4}{*}{ C4 } & 0 & 437 & $\mathrm{a}$ & $\mathrm{A}$ & 269 & $\mathrm{a}$ & $\mathrm{A}$ & 29.5 & $\mathrm{a}$ & $\mathrm{A}$ \\
\hline & 1.0 & 326 & $\mathrm{~b}$ & B & 212 & $\mathrm{~b}$ & B & 17.3 & $\mathrm{~b}$ & B \\
\hline & 2.5 & 271 & $b$ & $\mathrm{BC}$ & 202 & b & $\mathrm{BC}$ & 13.8 & $\mathrm{~b}$ & $\mathrm{BC}$ \\
\hline & 5.0 & 188 & $\mathrm{c}$ & $\mathrm{C}$ & 167 & c & $\mathrm{C}$ & 7.9 & $\mathrm{c}$ & $\mathrm{C}$ \\
\hline
\end{tabular}

${ }^{*}$ Each value is an average of 4 replications; ${ }^{* *}$ For each compost, data flanked in each column by the same letters are not statistically different according to Least Significant Difference Test (small letters for $\mathrm{P}=0.05$; capital letters for $\mathrm{P}=0.01$ ). 
Table 3. The effect of four composts, at different doses, on the suppression of Globodera pallida, pathotype Pa2

\begin{tabular}{|c|c|c|c|c|c|c|c|c|c|c|}
\hline \multirow[b]{2}{*}{ Compost } & \multirow{2}{*}{$\begin{array}{c}\text { Compost rate } \\
\% \text { w/w }\end{array}$} & \multicolumn{9}{|c|}{ Number } \\
\hline & & \multicolumn{3}{|c|}{ Cysts } & \multicolumn{3}{|c|}{$\begin{array}{c}\text { Eggs and } \\
\text { Juveniles/cyst }\end{array}$} & \multicolumn{3}{|c|}{$\begin{array}{c}\text { Eggs and } \\
\text { Juveniles/g soil }\end{array}$} \\
\hline \multirow{4}{*}{$\mathrm{C} 1$} & 0 & $386^{*}$ & $a^{* *}$ & $\mathrm{~A}$ & 348 & $\mathrm{a}$ & $\mathrm{A}$ & 35.3 & $\mathrm{a}$ & $\mathrm{A}$ \\
\hline & 1.0 & 324 & $\mathrm{~b}$ & $\mathrm{AB}$ & 275 & $\mathrm{~b}$ & B & 22.3 & $\mathrm{~b}$ & B \\
\hline & 2.5 & 303 & $\mathrm{~b}$ & B & 190 & $\mathrm{c}$ & $\mathrm{C}$ & 14.3 & $\mathrm{c}$ & $\mathrm{C}$ \\
\hline & 5.0 & 295 & $\mathrm{~b}$ & $\mathrm{~B}$ & 132 & d & $\mathrm{C}$ & 9.7 & $\mathrm{c}$ & $\mathrm{C}$ \\
\hline \multirow{4}{*}{$\mathrm{C} 2$} & 0 & 386 & $\mathrm{a}$ & A & 348 & $\bar{a}$ & $\mathrm{~A}$ & 35.3 & $a$ & $\mathrm{~A}$ \\
\hline & 1.0 & 203 & b & B & 248 & $\mathrm{~b}$ & B & 12.0 & $\mathrm{~b}$ & B \\
\hline & 2.5 & 146 & $\mathrm{c}$ & B & 123 & $\mathrm{c}$ & $\mathrm{C}$ & 4.6 & $\mathrm{c}$ & $\mathrm{C}$ \\
\hline & 5.0 & 79 & d & $\mathrm{C}$ & 97 & d & $\mathrm{C}$ & 2.4 & $\mathrm{c}$ & $\mathrm{C}$ \\
\hline \multirow{4}{*}{$\mathrm{C3}$} & 0 & 386 & $a b$ & A & 348 & $\mathrm{a}$ & $\mathrm{A}$ & 35.3 & $\mathrm{a}$ & $\mathrm{A}$ \\
\hline & 1.0 & 441 & $\mathrm{a}$ & A & 315 & $\mathrm{a}$ & A & 34.5 & $a b$ & A \\
\hline & 2.5 & 369 & b & A & 311 & $\mathrm{a}$ & A & 28.8 & b & A \\
\hline & 5.0 & 263 & $\mathrm{c}$ & $\mathrm{B}$ & 229 & $\mathrm{~b}$ & $\mathrm{~B}$ & 15.4 & $\mathrm{c}$ & $\mathrm{B}$ \\
\hline \multirow{4}{*}{$\mathrm{C} 4$} & 0 & 386 & $\mathrm{a}$ & A & 348 & $\mathrm{a}$ & $\mathrm{A}$ & 35.3 & $\mathrm{a}$ & $\mathrm{A}$ \\
\hline & 1.0 & 266 & $b$ & B & 254 & b & B & 17.1 & $\mathrm{~b}$ & B \\
\hline & 2.5 & 269 & $\mathrm{~b}$ & B & 211 & b & $\mathrm{BC}$ & 14.3 & $\mathrm{~b}$ & B \\
\hline & 5.0 & 163 & $\mathrm{c}$ & $\mathrm{C}$ & 154 & $\mathrm{c}$ & $\mathrm{C}$ & 6.5 & $\mathrm{c}$ & $\mathrm{C}$ \\
\hline
\end{tabular}

${ }^{*}$ Each value is an average of 4 replications; ${ }^{* *}$ For each compost, data flanked in each column by the same letters are not statistically different according to Least Significant Difference Test (small letters for $\mathrm{P}=0.05$; capital letters for $\mathrm{P}=0.01$ ).

the same time repositioning each plant within a block every week, to avoid a block position effect as well as the factor position of the potato plant within the block. The chemical analysis of the tested composts were performed from $10 \mathrm{~g}$ of each compost (Table 1) according to STN 465 735 analysis method (1991). The $\mathrm{pH}$ value (1:10 water extract, using a $\mathrm{pH}$ electrode) and dry matter (DM - drying at $105{ }^{\circ} \mathrm{C}$ to a constant weight) were determined. Portions of samples for $\mathrm{N}_{t}$ determination were digested using the
Didesdahl apparatus (Hach, Loveland, CO, U.S.A.). $\mathrm{N}_{\mathrm{t}}$ was distilled with $\mathrm{NaOH}$ (40 \%) (Bremner,1996). Watersoluble ammonium nitrogen $\left(\mathrm{NH}_{4}{ }^{+}\right)$was determined by titration (Mulvaney, 1996). The $\mathrm{C}$ content was calculated according to the content of organic matter (OM) by the method of Navarro et al., (1993). Also, the C:N ratio was calculated. After three months, a $500 \mathrm{~g}$ soil sample was collected from each pot and cysts were extracted by the flotation method (Sabová \& Valocká, 1980) of infested soil

Table 4. The effect of four composts, at different doses, on suppression of Globodera pallida, pathotype Pa3

\begin{tabular}{|c|c|c|c|c|c|c|c|c|c|c|}
\hline \multirow[b]{2}{*}{ Compost } & \multirow{2}{*}{$\begin{array}{c}\text { Compost rate } \\
\% \text { w/w }\end{array}$} & \multicolumn{9}{|c|}{ Number } \\
\hline & & \multicolumn{3}{|c|}{ Cysts } & \multicolumn{3}{|c|}{$\begin{array}{c}\text { Eggs and } \\
\text { Juveniles/cyst }\end{array}$} & \multicolumn{3}{|c|}{$\begin{array}{c}\text { Eggs and } \\
\text { Juveniles/g soil }\end{array}$} \\
\hline \multirow{4}{*}{$\mathrm{C1}$} & 0 & $566^{*}$ & $a^{* *}$ & $\mathrm{~A}$ & 370 & $\mathrm{a}$ & $\mathrm{A}$ & 52.4 & $\mathrm{a}$ & $\mathrm{A}$ \\
\hline & 1.0 & 464 & $\mathrm{~b}$ & $\mathrm{AB}$ & 305 & $\mathrm{~b}$ & B & 35.3 & b & B \\
\hline & 2.5 & 373 & $\mathrm{~b}$ & $\mathrm{BC}$ & 294 & $\mathrm{~b}$ & B & 27.3 & $\mathrm{c}$ & B \\
\hline & 5.0 & 272 & $\mathrm{c}$ & $\mathrm{C}$ & 214 & $\mathrm{c}$ & $\mathrm{C}$ & 14.5 & d & $\mathrm{C}$ \\
\hline \multirow{4}{*}{$\mathrm{C} 2$} & 0 & 566 & $\mathrm{a}$ & A & 370 & $\mathrm{a}$ & $\mathrm{A}$ & 52.4 & $\mathrm{a}$ & A \\
\hline & 1.0 & 168 & $b$ & B & 164 & $\mathrm{~b}$ & B & 6.8 & $\mathrm{~b}$ & B \\
\hline & 2.5 & 118 & b & $\mathrm{BC}$ & 115 & $\mathrm{c}$ & $\mathrm{C}$ & 3.3 & $\mathrm{~b}$ & B \\
\hline & 5.0 & 32 & $\mathrm{c}$ & $\mathrm{C}$ & 110 & $\mathrm{c}$ & $\mathrm{C}$ & 0.9 & $\mathrm{~b}$ & $\mathrm{~B}$ \\
\hline \multirow{4}{*}{ C3 } & 0 & 566 & $\mathrm{a}$ & $\mathrm{A}$ & 370 & $\mathrm{a}$ & $\mathrm{A}$ & 52.4 & $\mathrm{a}$ & $\mathrm{A}$ \\
\hline & 1.0 & 408 & $\mathrm{~b}$ & B & 372 & $\mathrm{a}$ & A & 38.3 & $\mathrm{~b}$ & $\mathrm{AB}$ \\
\hline & 2.5 & 252 & $\mathrm{c}$ & $\mathrm{C}$ & 356 & $\mathrm{a}$ & A & 36.0 & $b$ & B \\
\hline & 5.0 & 162 & $\mathrm{~d}$ & $\mathrm{C}$ & 286 & $\mathrm{~b}$ & B & 21.0 & $\mathrm{c}$ & $\mathrm{C}$ \\
\hline \multirow{4}{*}{$\mathrm{C} 4$} & 0 & 566 & $\mathrm{a}$ & $\mathrm{A}$ & 370 & $\mathrm{a}$ & $\mathrm{A}$ & 52.4 & $\mathrm{a}$ & $\mathrm{A}$ \\
\hline & 1.0 & 408 & $\mathrm{~b}$ & B & 305 & $\mathrm{~b}$ & B & 31.6 & $\mathrm{~b}$ & B \\
\hline & 2.5 & 252 & $\mathrm{c}$ & $\mathrm{C}$ & 225 & $\mathrm{c}$ & $\mathrm{BC}$ & 14.3 & $\mathrm{c}$ & $\mathrm{C}$ \\
\hline & 5.0 & 214 & $\mathrm{c}$ & $\mathrm{C}$ & 356 & $\mathrm{a}$ & $\mathrm{C}$ & 13.8 & $\mathrm{c}$ & $\mathrm{C}$ \\
\hline
\end{tabular}

"Each value is an average of 4 replications; ${ }^{* *}$ For each compost, data flanked in each column by the same letters are not statistically different 186 according to Least Significant Difference Test (small letters for $\mathrm{P}=0.05$; capital letters for $\mathrm{P}=0.01$ ). 
Table 5. General comparison among compost rates on different pathotypes of the Potato Cyst Nematodes (PCN) G. rostochiensis and G. pallida

\begin{tabular}{|c|c|c|c|c|c|c|c|c|c|c|}
\hline \multirow[b]{2}{*}{$\begin{array}{l}\text { Nematode/ } \\
\text { pathotype }\end{array}$} & \multirow{2}{*}{$\begin{array}{c}\text { Compost } \\
\text { rate } \\
\% \mathrm{w} / \mathrm{w}\end{array}$} & \multicolumn{9}{|c|}{ Number } \\
\hline & & \multicolumn{3}{|c|}{ Cysts } & \multicolumn{3}{|c|}{$\begin{array}{c}\text { Eggs and } \\
\text { Juveniles/cyst }\end{array}$} & \multicolumn{3}{|c|}{$\begin{array}{c}\text { Eggs and } \\
\text { Juveniles/g soil }\end{array}$} \\
\hline \multirow{4}{*}{$\begin{array}{c}\text { Globodera } \\
\text { rostochiensis } \\
\text { Ro1 }\end{array}$} & 0 & $437^{*}$ & $a^{* *}$ & $\mathrm{~A}$ & 267 & $\mathrm{a}$ & $\mathrm{A}$ & 29.5 & $\mathrm{a}$ & $\mathrm{A}$ \\
\hline & 1.0 & 293 & $\mathrm{~b}$ & B & 220 & $\mathrm{~b}$ & B & 16.3 & $\mathrm{~b}$ & B \\
\hline & 2.5 & 252 & $\mathrm{bc}$ & $\mathrm{BC}$ & 181 & $\mathrm{c}$ & $\mathrm{C}$ & 11.6 & $\mathrm{c}$ & $\mathrm{BC}$ \\
\hline & 5.0 & 195 & $\mathrm{c}$ & $\mathrm{C}$ & 145 & $\mathrm{~d}$ & $\mathrm{D}$ & 7.5 & $\mathrm{~d}$ & $\mathrm{C}$ \\
\hline \multirow{4}{*}{$\begin{array}{c}\text { Globodera } \\
\text { pallida } \\
\text { Pa2 }\end{array}$} & 0 & 386 & $\mathrm{a}$ & $\mathrm{A}$ & 348 & $\mathrm{a}$ & $\mathrm{A}$ & 32.8 & $\mathrm{a}$ & $\mathrm{A}$ \\
\hline & 1.0 & 308 & $\mathrm{~b}$ & $\mathrm{AB}$ & 273 & $\mathrm{~b}$ & B & 21.5 & $\mathrm{~b}$ & B \\
\hline & 2.5 & 271 & $\mathrm{~b}$ & BC & 209 & $\mathrm{c}$ & $\mathrm{C}$ & 15.5 & $\mathrm{c}$ & $\mathrm{BC}$ \\
\hline & 5.0 & 200 & $\mathrm{c}$ & $\mathrm{C}$ & 153 & $\mathrm{~d}$ & $\mathrm{D}$ & 8.5 & $\mathrm{~d}$ & $\mathrm{C}$ \\
\hline \multirow{4}{*}{$\begin{array}{c}\text { Globodera } \\
\text { pallida } \\
\text { Pa3 }\end{array}$} & 0 & 566 & $\mathrm{a}$ & $\mathrm{A}$ & 370 & $\mathrm{a}$ & A & 52.4 & $\mathrm{a}$ & A \\
\hline & 1.0 & 363 & $\mathrm{~b}$ & B & 293 & $\mathrm{~b}$ & B & 27.9 & $\mathrm{~b}$ & B \\
\hline & 2.5 & 248 & $\mathrm{c}$ & $\mathrm{C}$ & 247 & $\mathrm{bc}$ & $\mathrm{BC}$ & 20.2 & $\mathrm{bc}$ & $\mathrm{BC}$ \\
\hline & 5.0 & 170 & $\mathrm{~d}$ & $\mathrm{C}$ & 217 & $\mathrm{c}$ & $\mathrm{C}$ & 12.6 & $\mathrm{c}$ & $\mathrm{C}$ \\
\hline
\end{tabular}

*Each value is an average of 4 replications; ${ }^{* *}$ For the same pathotype, data flanked in each column by the same letters are not statistically different according to Least Significant Difference Test (small letters for $\mathrm{P}=0.05$; capital letters for $\mathrm{P}=0.01$ ).

of each pot. The extracted cysts were crushed, and the number of viable eggs and second-stage juveniles $\left(\mathrm{J}_{2}\right)$ were counted. Data were statistically analysed by the factorial analysis of variance (ANOVA) and means compared by the Least Significant Difference Test at $\mathrm{P}=0.05$ and 0.01 . Statistical analyses were performed using the PlotIT program. TableCurve program was used to analyze the relationships between different compost doses and nematological parameters of potato cysts nematodes.

\section{Results}

\section{Chemical analysis of composts}

Results from chemical analysis of the four composts are reported in Table 1. The value of $\mathrm{pH}$ was neutral (7.00) only in $\mathrm{C} 4$ compost. In all other composts, it was lightly alkaline, and it ranged between 7.7 and 8.4. The lowest percentage of dry matter (DM) was observed in the $\mathrm{C} 1$ compost based on horse manure with the addition of different percentages of poultry manure, sugar beet and grape pomace. The highest DM percentage was found in $\mathrm{C} 2$ compost based on Musca domestica decomposed pig manure. In $\mathrm{C} 3$ and $\mathrm{C} 4, \mathrm{DM}$ percentages were 59.68 and 69.00 , respectively. The compost $\mathrm{C} 2$ contained the highest level of the total nitrogen $\left(\mathrm{N}_{\mathrm{t}}\right)(24,465 \mathrm{mg} / \mathrm{Kg} \mathrm{DM})$, followed by the $\mathrm{C} 4$ compost. The lowest $\mathrm{N}_{\mathrm{t}}$ content was observed in $\mathrm{C} 3$ compost. The content of $\mathrm{NH}_{4}{ }^{+}$was highest in $\mathrm{C} 2$ compost according to the highest $\mathrm{Nt}$ level observed in the same compost. In $\mathrm{C} 3$ and $\mathrm{C} 4$ composts, the $\mathrm{NH}_{4}^{+}$ contents were about 9 and 13 times lower than that observed in $\mathrm{C} 2$ compost, respectively. The highest available carbon content was recorded in $\mathrm{C} 4$ compost $(27,000 \mathrm{mg} / \mathrm{Kg} \mathrm{DM})$ at which corresponded the lowest $\mathrm{C}: \mathrm{N}$ ratio (9.2:1) (Table 1).

Table 6. General comparison among composts and their effects on different pathotypes of the Potato Cyst Nematodes (PCN) G. rostochiensis and G. pallida

\begin{tabular}{|c|c|c|c|c|c|c|c|c|c|c|}
\hline \multirow{2}{*}{$\begin{array}{l}\text { Nematode/ } \\
\text { pathotype }\end{array}$} & \multirow{2}{*}{ Compost } & \multicolumn{9}{|c|}{ Number } \\
\hline & & \multicolumn{3}{|c|}{ Cysts } & \multicolumn{3}{|c|}{$\begin{array}{c}\text { Eggs and } \\
\text { Juveniles/cyst }\end{array}$} & \multicolumn{3}{|c|}{$\begin{array}{c}\text { Eggs and } \\
\text { Juveniles/g soil }\end{array}$} \\
\hline \multirow{4}{*}{$\begin{array}{c}\text { Globodera } \\
\text { rostochiensis } \\
\text { Ro1 }\end{array}$} & $\mathrm{C}_{1}$ & $295^{*}$ & $\mathrm{~b}^{* *}$ & B & 182 & $\mathrm{a}$ & $\mathrm{A}$ & 14.7 & $\mathrm{a}$ & $\mathrm{AB}$ \\
\hline & $\mathrm{C}_{2}$ & 187 & $\mathrm{a}$ & A & 197 & $a b$ & A & 12.9 & $\mathrm{a}$ & B \\
\hline & $\mathrm{C}_{3}$ & 390 & $\mathrm{c}$ & B & 223 & b & A & 22.0 & $\mathrm{~b}$ & A \\
\hline & $\mathrm{C}_{4}$ & 306 & $\mathrm{~b}$ & $\mathrm{~B}$ & 213 & $\mathrm{ab}$ & A & 17.1 & $a b$ & $\mathrm{AB}$ \\
\hline \multirow{4}{*}{$\begin{array}{c}\text { Globodera } \\
\text { pallida } \\
\text { Pa2 }\end{array}$} & $\mathrm{C}_{1}$ & 327 & $\mathrm{bc}$ & $\mathrm{BC}$ & 236 & $\mathrm{a}$ & $\mathrm{AB}$ & 19.8 & $\mathrm{a}$ & $\mathrm{AB}$ \\
\hline & $\mathrm{C}_{2}$ & 203 & $\mathrm{a}$ & A & 204 & $\mathrm{a}$ & A & 12.9 & $\mathrm{a}$ & A \\
\hline & $\mathrm{C}_{3}$ & 365 & $\mathrm{c}$ & $\mathrm{C}$ & 301 & $\mathrm{~b}$ & B & 27.8 & $\mathrm{~b}$ & B \\
\hline & $\mathrm{C}_{4}$ & 272 & $\mathrm{~b}$ & $\mathrm{AB}$ & 242 & $a b$ & $\mathrm{AB}$ & 17.6 & $\mathrm{a}$ & $\mathrm{AB}$ \\
\hline \multirow{4}{*}{$\begin{array}{c}\text { Globodera } \\
\text { pallida } \\
\text { Pa3 }\end{array}$} & $\mathrm{C}_{1}$ & 419 & $\mathrm{a}$ & $\mathrm{A}$ & 295 & $\mathrm{a}$ & $\mathrm{A}$ & 32.4 & $\mathrm{a}$ & $\mathrm{A}$ \\
\hline & $\mathrm{C}_{2}$ & 221 & $\mathrm{~b}$ & B & 189 & $\mathrm{~b}$ & B & 15.8 & $\mathrm{~b}$ & B \\
\hline & $\mathrm{C}_{3}$ & 347 & $\mathrm{a}$ & A & 346 & $\mathrm{a}$ & A & 36.9 & $\mathrm{a}$ & A \\
\hline & $\mathrm{C}_{4}$ & 360 & $\mathrm{a}$ & A & 295 & $\mathrm{a}$ & A & 27.8 & $\mathrm{a}$ & $\mathrm{AB}$ \\
\hline
\end{tabular}

*Each value is an average of 4 replications; ${ }^{* *}$ For the same pathotype, data flanked in each column by the same letters are not statistically different according to Least Significant Difference Test (small letters for $\mathrm{P}=0.05$; capital letters for $\mathrm{P}=0.01$ ). 
Table 7. Relationship between ammoniacal content $\left(\mathrm{NH}_{4}{ }^{+}\right)$in the different composts and number of cysts, eggs and juveniles/cyst and eggs and juveniles/g soil of different pathotypes of potato cyst nematodes (PCN)

\begin{tabular}{c|c|c|c}
\hline $\begin{array}{c}\text { Nematological } \\
\text { parameter }\end{array}$ & PCN and pathotype & Equation & $r$ \\
\hline $\mathrm{N}^{\circ}$ cysts & G. rostochiensis $\mathrm{Ro} 1$ & $\mathrm{y}=508.82-30.94 * \mathrm{x}^{0.326}$ & -0.944 \\
& G. pallida Pa2 & $\mathrm{y}=327.02-8.566 \mathrm{e}-05 * \mathrm{x}^{1.986}$ & -0.834 \\
& G. pallida Pa3 & $\mathrm{y}=376.37-3.706 \mathrm{e}-09 * \mathrm{x}^{3.425}$ & -0.917 \\
\hline $\mathrm{N}^{\circ}$ eggs and J2/cyst & G. rostochiensis $\mathrm{Ro} 1$ & $\mathrm{y}=189.76+108.41^{(-\mathrm{x} / 98.71)}$ & -0.920 \\
& G. pallida Pa2 & $\mathrm{y}=213.83+1,054,869.7 / \mathrm{x}^{2}$ & -0.950 \\
& G. pallida Pa3 & $\mathrm{y}=342.81-0.171 * \mathrm{x}^{0.951}$ & -0.959 \\
\hline $\mathrm{N}^{\circ}$ eggs and J2/g soil & G. rostochiensis Ro1 & $\mathrm{y}=13.43+104,376.23 / \mathrm{x}^{2}$ & -0.990 \\
& G. pallida Pa2 & $\mathrm{y}=15.04+148079.45 / \mathrm{x}^{2}$ & -0.866 \\
& G. pallida Pa3 & $\mathrm{y}=32.61-8.398 \mathrm{e}-09 * \mathrm{x}^{3}$ & -0.912 \\
\hline
\end{tabular}

Suppression of the cyst nematode populations G. rostochiensis and G. pallida.

The four compost significantly reduced the final soil cyst nematode $G$. rostochiensis population, pathotype Ro1, in comparison to untreated soil (control - 0 dose), even at the lowest amendment rate $(1 \%)$ irrespective of the compost origin (Table 2) with the exception of dose at $1 \%$ of compost $\mathrm{C} 3$ for the number of cysts and eggs and juveniles/g soil (Table 2).

The lowest effective control of the cyst nematode population $G$. rostochiensis (Ro1) was observed in the compost $\mathrm{C} 3(\mathrm{P}=0.05)$. No statistical differences were observed in number of cysts among the different $\mathrm{C} 3$ compost rates at 0.01 level $(\mathrm{P}=0.01)$, including the untreated control. This non effective control could be attributed the lowest value of $\mathrm{NH}_{4}{ }^{+}$contents recorded in the chemical analysis of compost C3 (Table $1-2$ ). The highest significantly cyst nematode reduction $\left(\mathrm{N}^{\circ}\right.$ of cysts, eggs and juveniles/cyst and eggs and juveniles/g soil) was observed at the highest rate of each compost ( $5 \%$ ) (Table 2 ).

The effects of the different rates of the four composts on G. pallida, pathotype $\mathrm{Pa} 2$ and $\mathrm{Pa} 3$, are reported in Table 3 and 4 , respectively.

The number of G. pallida ( $\mathrm{Pa} 2)$ cysts, eggs and juveniles per cyst and per $\mathrm{g}$ soil was significantly already reduced at the lowest amendment dose (1\%) of $\mathrm{C} 1, \mathrm{C} 2$ and $\mathrm{C} 4$ composts $(\mathrm{P}=0.05)$. In the compost $\mathrm{C} 3$, with the lowest $\mathrm{NH}_{4}^{+}$ content, only the highest dose $(5 \% \mathrm{w} / \mathrm{w})$ was effective to reduce the number of cysts, eggs and juveniles per cyst and per $g$ soil $(\mathrm{P}=0.01)$ (Table 3$)$. The number of cysts and eggs and juveniles per $\mathrm{g}$ soil of the pathotype Pa3 of $G$. pallida was significantly reduced by all doses of compost C3 (Table 4) in contrast with the previous results obtained with same compost for G. rostochiensis (Ro1) and G. palli$d a(\mathrm{~Pa} 2)$. Only the number of G. pallida (Pa3) eggs and juveniles per cyst was not reduced amending the soil with C3 compost with the exception of the highest dose (Table 4). In general, the highest significative reductions of all nematological parameters for $G$. rostochiensis (Ro1) and G. pallida ( $\mathrm{Pa} 2$ and $\mathrm{Pa} 3)$, in almost all composts, were obtained with $5 \%(\mathrm{w} / \mathrm{w})$ soil amendment rate, independently from the type compost.

\section{General comparison among compost rates}

In each soil amended with the four composts, a significant reduction of the number of cysts in $400 \mathrm{~g}$ soil samples, eggs and juveniles per cyst and per g soil was observed in comparison with unamended soil (control at $0 \%$ dose) for all the different considered pathotypes of G. rostochiensis (Ro1) and G. pallida ( $\mathrm{Pa} 2$ and $\mathrm{Pa} 3$ ), even at the lowest amendment rate $(1 \% \mathrm{w} / \mathrm{w})$ irrespective of the compost origin (Table 5). These results confirm the reduced nematode reproduction in the compost treated soil, and they highlighted that number of cysts, eggs and juveniles per cyst and per $g$ amended soil decreased linearly as compost rate soil addition increased (Table 5).

\section{General comparison among composts}

G. rostochiensis (Ro1) females were significantly suppressed only by the compost $\mathrm{C} 2$ in comparison to the other composts which were not statistically different from each other $(P=0.01)$ (Table 6). Also, the numbers of eggs and juveniles per g soil were significantly lower in soil amended with the compost $\mathrm{C} 2$ compared to compost $\mathrm{C} 3$ and no evident and significant differences were found among $\mathrm{C} 2$ and $\mathrm{C} 1$ and $\mathrm{C} 4$ compost, although these two latter composts were not significantly different from $\mathrm{C} 3(\mathrm{P}=0.01)$ (Table 6). The number of eggs and juveniles per cyst was not influenced by the different tested composts $(\mathrm{P}=0.01)$ (Table 6).

For $G$. pallida $(\mathrm{Pa} 2)$, a significant reduction in the cysts number was observed in soil treated with the compost $\mathrm{C} 2$ $(\mathrm{P}=0.05)$ in comparison to all other composts (Table 6). A significant difference in number of eggs and juveniles per cyst and per $g$ soil was found only between the lowest and highest value observed in soil amended with compost $\mathrm{C} 2$ and $\mathrm{C} 3$, respectively.

The highest and significant reduction of the number of cysts, eggs and juveniles per cyst and per g soil was observed in $\mathrm{C} 2$ compost treated soil in comparison to all other compost amended soils $(\mathrm{P}=0.05)$ (Table 6).

Relationship between different doses of C1, C2, C3 and C4 composts and nematological parameters.

Based on the results, significant negative correlations were found in the relationship between the different applied 

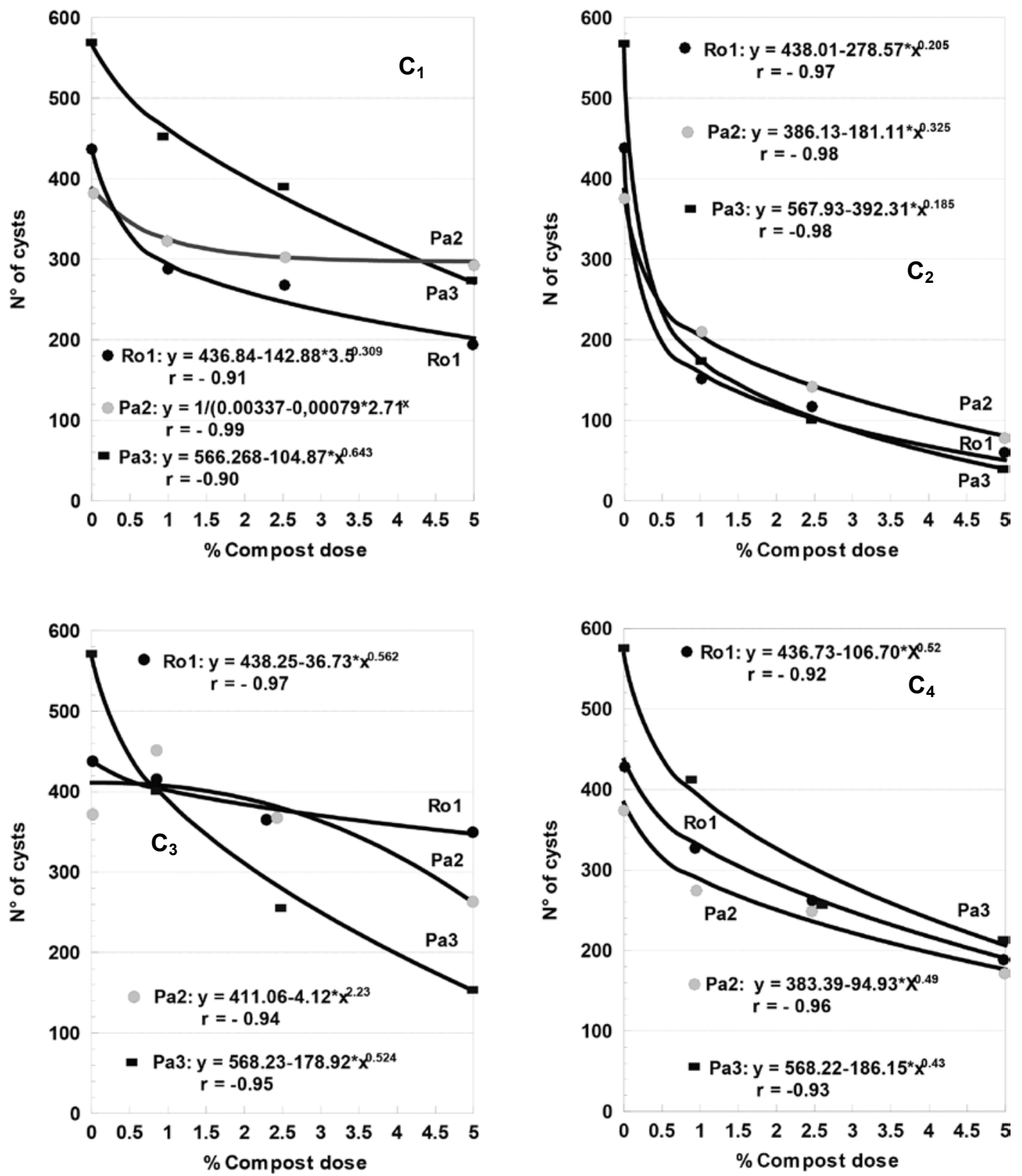

Fig 1. Relationships between different doses of $\mathrm{C}_{1}, \mathrm{C}_{2}, \mathrm{C}_{3}$ and $\mathrm{C}_{4}$ composts on number of cysts of Globodera rostochiensis (pathotype Ro1) and G. pallida (pathotypes $\mathrm{Pa} 2$ and $\mathrm{Pa} 3$ )

doses of $\mathrm{C} 1, \mathrm{C} 2, \mathrm{C} 3$ and $\mathrm{C} 4$ composts and the values of the number of cysts (Fig. 1), eggs and juveniles/cysts (Fig. 2) and eggs and juveniles/g soil (Fig. 3) of G. rostochiensis Ro1, G. pallida $\mathrm{Pa} 2$ and $\mathrm{Pa} 3$. The equations reasonably explain the above relationships, as indicated by the high values of the correlation coefficients $(r)$.

Also, the relationships of compost $\mathrm{NH}_{4}{ }^{+}$content and the number of cysts, eggs and juveniles/cyst and per $\mathrm{g}$ soil were analysed. All these nematological parameters were significantly and negatively correlated with the $\mathrm{NH}_{4}{ }^{+}$content of composts with the exception of $G$. pallida $\mathrm{Pa} 2$ for the number of cysts and eggs and juveniles/g soil (Table 7).

\section{Discussion and Conclusions}

Survival and reproduction rates of the PCN G. rostochiensis (Ro1) and G. pallida ( $\mathrm{Pa} 2$ and $\mathrm{Pa} 3$ ) deriving from the four tested composts incorporated into the soil at four different rates were analysed and compared with each other. The compost C1, C2 and C4 were more effective to reduce the cysts number of the pathotypes Ro1 and $\mathrm{Pa} 2$ of $\mathrm{PCN}$ in comparison to $\mathrm{C} 3$ compost, irrespective to the compost dose. These findings agree with those deriving from $G$. rostochiensis (Ro1) with other composts of different origin applied at the same rates $(0,1,2.5$ and $5 \%)$ to 

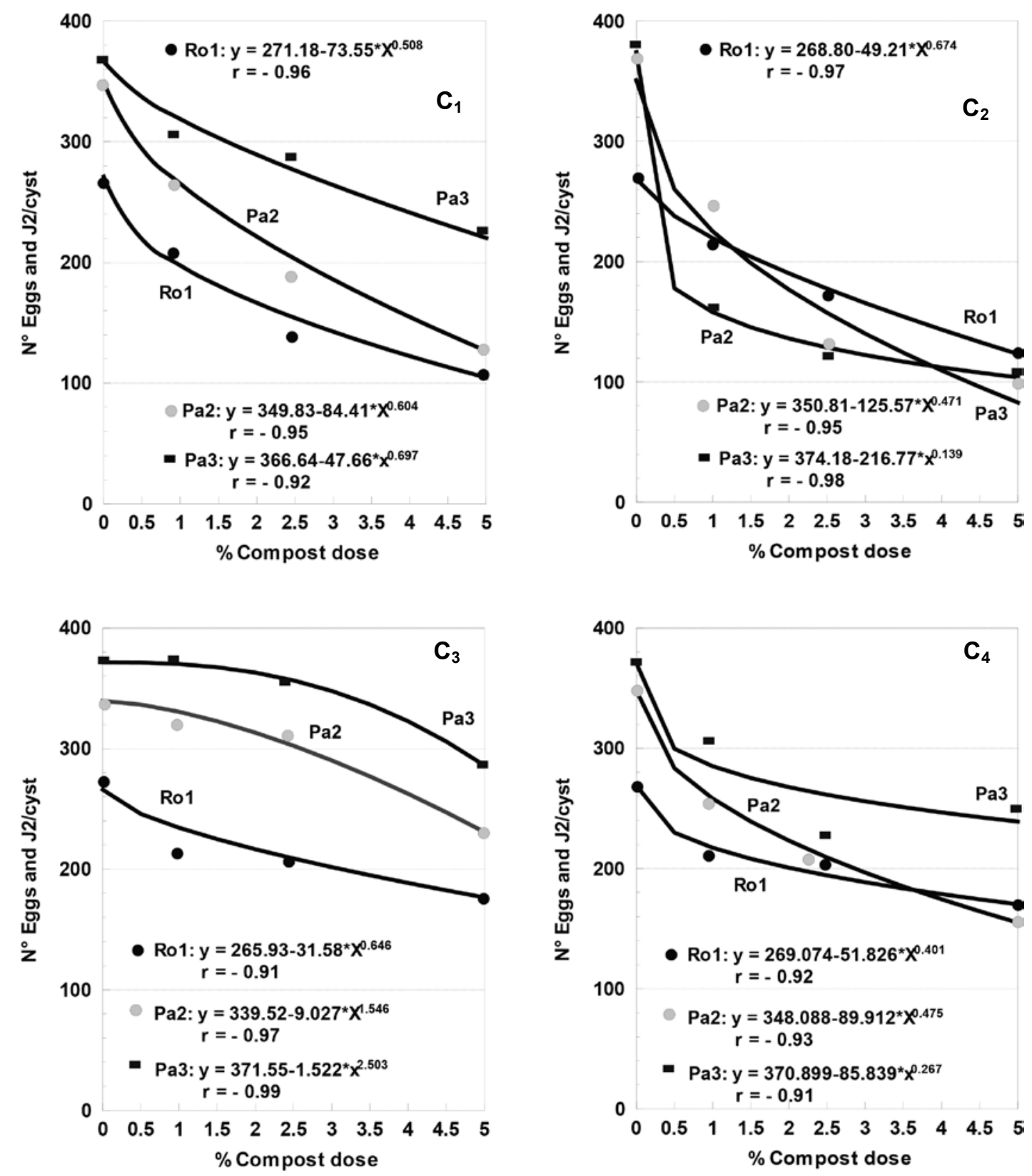

Fig 2. Relationships between different doses of $\mathrm{C}_{1}, \mathrm{C}_{2}, \mathrm{C}_{3}$ and $\mathrm{C}_{4}$ composts on eggs and $\mathrm{J}_{2}$ /cyst of Globodera rostochiensis (pathotype Ro1) and G. pallida (pathotypes $\mathrm{Pa} 2$ and $\mathrm{Pa} 3$

the soil (Renčo et al., 2007). A similar strong reduction of Heterodera schachtii population was observed in infested soils amended with compost (Schlang, 1993), although a vermicompost derived from cattle manure showed no inhibitory effect on the same plant parasitic nematode (Szczech et al., 1993). Results from our experiment are partially in agreement with those reported by Szczech (1993) because of no statistical differences were observed between the compost $\mathrm{C} 4$ (vermicompost based on cattle manure) and the lowest effective compost $\mathrm{C} 3$ in the reduction of the number of cysts, eggs and juveniles per cyst and per $g$ soil, at a different level of probability, with the exception of the number of $G$. pallida $\mathrm{Pa} 2$ cysts. Some vermicomposts, similar to that used in our experiment confirm no nematicidal effect on the cyst nematode Heterodera trifolii (Kimpiski et al., 2003). On the contrary, a vermicompost was effective in the control of Pratylenchus coffeae and Helicotylenchus multicinctus, which are no cyst nematodes (Sundararaju et al., 2002). In soil infested by sedentary endoparasite Rotylenchulus reniformis a significant nematode reduction was observed adding different doses of biofertilizers and olive pomace based compost into the soil, with a significantly positive correlation between applied doses of compost treatments and reduction of nematode populations (Ismail et al., 2006).

Probably, the cyst nematodes are more resistant than endoparasitic, ectoparasitic and sedentary ectoparasitic nema- 

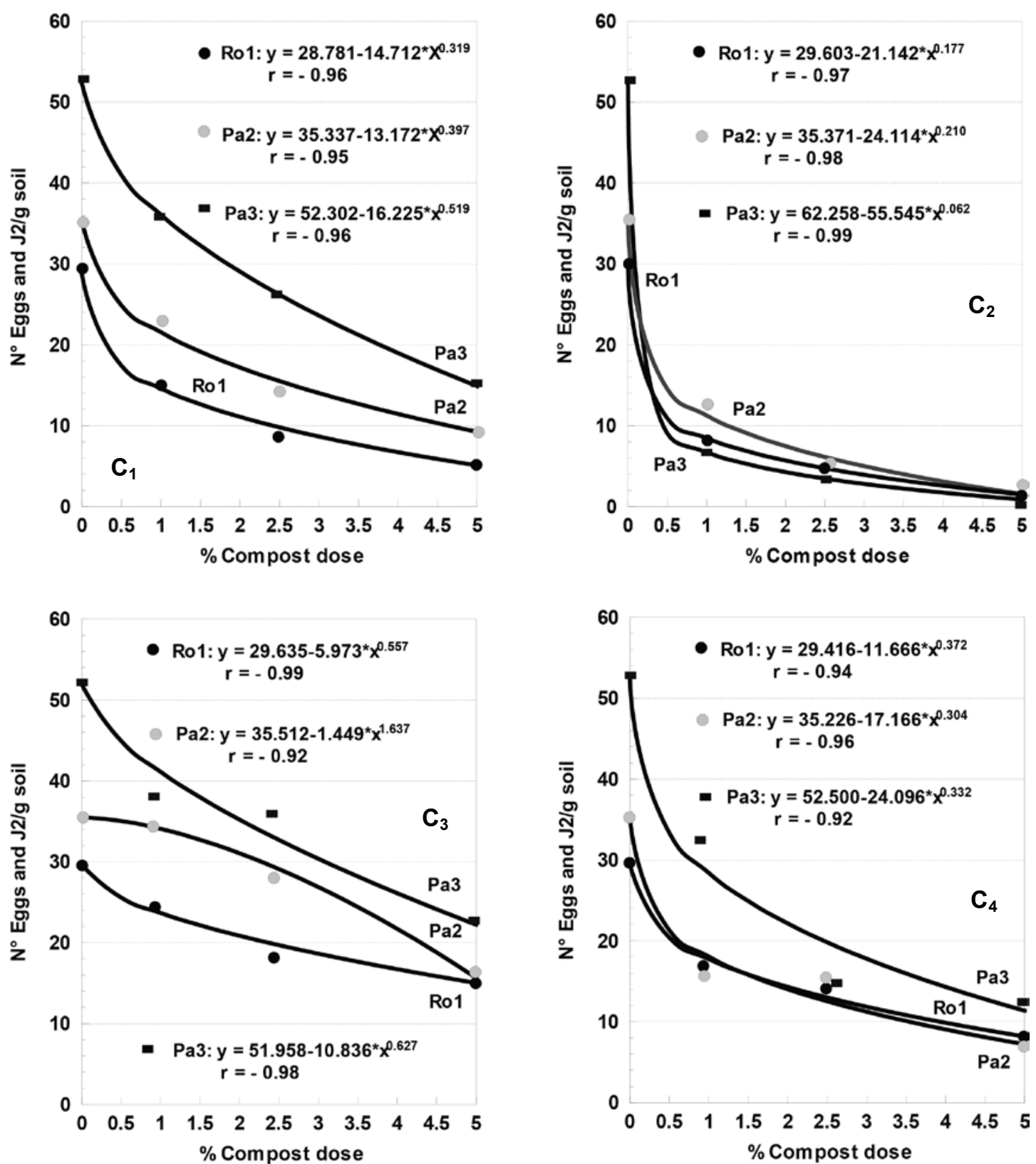

Fig 3. Relationships between different doses of $\mathrm{C}_{1}, \mathrm{C}_{2}, \mathrm{C}_{3}$ and $\mathrm{C}_{4}$ composts on eggs and $\mathrm{J}_{2} / \mathrm{g}$ soil of Globodera rostochiensis (pathotype Ro1) and G. pallida (pathotypes $\mathrm{Pa} 2$ and $\mathrm{Pa} 3$ )

todes because of the presence of the layer of dead cuticle of females, which serves to protect the eggs, and secondstage juveniles that are retained within (Zunke \& Eisenback, 1998). In addition, the lower nematicidal effect of compost $\mathrm{C} 3$ and $\mathrm{C} 4$ can be reasonably explained also by the lowest $\mathrm{NH}_{4}^{+}$content $(112$ and $168 \mathrm{mg} / \mathrm{kg} \mathrm{DM}$, respectively) (Table 1).

The nematicidal activity of the different organic amendments is also influenced by the $\mathrm{C}: \mathrm{N}$ ratio, amount of amendment used and on the decomposition time (Akhtar \& Malik, 2000). The use of nitrogen by plants due to the microbial decomposition is also dependent by $\mathrm{C}: \mathrm{N}$ ratio. A C:N ratio, in organic matter, greater than 20:1, temporarily can immobilised $\mathrm{N}$ in microbial tissues creating an
$\mathrm{N}$-deficient uptake in plants. On the contrary, in residues or wastes with a C:N ratio less than $20: 1$, N can be mineralised in $\mathrm{NH}_{4}^{+}$or $\mathrm{NO}_{3}{ }^{-}$for absorption by plant root systems. The availability of more $\mathrm{N}$ enhances the nematicidal activity against plant parasitic nematodes of the organic amendments, as also reported by Mian \& RodriguezKábana (1982). Sometimes the incorporation of organic matter into the soil can create phytotoxic problem. The addition of nitrogen sources to fresh organic matter may increase the nematicidal effect, enabling it to be used at lower dosages and thus reducing phytotoxicity (RodriguezKábana et al., 1992; 1995; Sasanelli et al., 2006).

The most effective compost in the control of both PCN $G$. rostochiensis and $G$. pallida was the compost $\mathrm{C} 2$. In par- 
ticular, this compost showed a significant nematicide effect especially on the pathotype $\mathrm{Pa} 3$ in comparison to all other composts (Table 6). This highest nematicidal activity could be explained by the highest DM (87.8 \% - Table 1) and $\mathrm{NH}_{4}{ }^{+}$content observed in the compost C2 $(1,260 \mathrm{mg} / \mathrm{Kg}$ DM - Table 1). Moreover, in previous studies the same compost was found to improve significantly yield of broccoli and sunflower (Kováčik et al., 2008; 2010).

In conclusion, data from our experiment confirm that the use of composts may present a valuable possibility for an eco-compatible management of the PCN G. rostochiensis (Ro1) and G. pallida ( $\mathrm{Pa} 2$ and $\mathrm{Pa} 3$ ), especially if amendment soils are applied for consecutive years, as it was previously demonstrated on root-knot nematodes (D'Addabbo et al., 2003).

In particular, the compost $\mathrm{C} 2$, based on pig manure transformed by larvae of house flies, had a positive effect on soil organic matter improving soil quality and fertility and plant tolerance to nematode attack (McSorley \& Gallagher, 1995; Everts et al., 2006). The marked suppressive effect on reproduction of females, number of eggs and juveniles per cyst and per $g$ of soil, was showed even at the lowest rate of compost addition ( $1 \%)$ confirming its importance for field application in PCN control. However, the positive results observed in composts with different origin and composition suggests that the formulation of compost must be based on locally available wastes in order to provide composts at low cost without reducing their technical validity, especially in nematicidal efficacy.

\section{Acknowledgement}

The research was undertaken within the framework of a bilateral project between the Italian National Council of Research and the Slovak Academy of Sciences (2010 2012). The authors acknowledge the support of the scientific grant agency VEGA (Grant $N^{\circ} 2 / 0136 / 10$ ) and (Grant $\left.\mathrm{N}^{\circ} 1 / 0654 / 10\right)$ and Mr. Fabio Catalano for technical assistance.

\section{References}

ABAWI, G. S., WIDMER, T. L. (2000): Impact of soil health management practices on soil born pathogens, nematodes and root diseases of vegetable crops. Appl. Soil Ecol. 15: 37 - 47. DOI: 10.1016/S0929-1393(00)00070-6

AGBenin, O. N. (2004): Potentials of organic amendemnts in the control of plant parasitic nematodes. Plant Protect. Sci., 40: $21-25$

AKHTAR, M., MALIK, A. (2000): Roles of organic soil amendments and soil organisms in the biological control of plant-parasitic nematodes: a review. Bioresour. Technol., 74: 35 - 47. DOI: 10.1016/S0960-8524(99)00154-6 ATUNGWU, J. J. (2005): An overview of the impact of organic manure as plant parasitic nematode suppressant. Proceedings, $1^{\text {st }}$ National Conference on Organic Agriculture, UNAAB, Abeokuta, Nigeria, $25-28^{\text {th }}$ October

BAILEY, L. L., LAZAROVITS, G. (2003): Suppressing soil- borne diseases with residue management and organic amendments. Soil \& Tillage Res., 72: 169 - 180. DOI: 10.1 016/s0167-1987(03)00086-2

BREMNER, J. M. (1996): Nitrogen - TOTAL. In: SPARKS D. L. (Ed). Methods of soil analysis . Part 3 - Chemical methods. Books series 5. MADISON, WI, U.S.A. Soil Science Society of America. pp. $1085-1121$

Castillo, P., Nico, A. I., Azcon-Aguilar, C., Del Rio Rincon, C., Calvet, C., Jimenez-Diaz, R. M. (2006): Protection of olive planting stocks against parasitism of root-knot nematodes by arbuscular mycorrhizal fungi. Plant Pathol., 55(5): 705 - 713. DOI: 10.1111/j.1365-30 59.2006.01400.x

D’AddabBo, T., Fontanazza, G., LAmberti, F., SASANELli, N., PATUMI, M. (1997): The suppressive effect of soil amendments with olive residues on Meloidogyne incognita. Nematol. Mediterr., 25: 195 - 198

D’AddabBo, T., SASAnElli, N., LAmberti, F., CARElla, A. (2000): Control of root-knot nematodes by olive and grape pomace soil amendments. Acta Hortic., 532: 53 - 57 D'AdDabBo, T., SASANElli, N. (2003): Control of phytoparasitic nematodes by biocidal plants. Atti XXXV Convegno SIA, $\mathrm{N}^{\circ} 23$; Napoli, 16 - 18 settembre: 363 - 364 (In Italian)

D’Addabbo, T., Sasanelli, N., Lamberti, F., Greco, P., CARella, A. (2003): Olive pomace and chicken manure amendments for the control of Meloidogyne incognita over two crop cycles. Nematropica, 33: $1-7$

D’Addabbo, T., Sasanelli, N., Greco, N., Stea, V., Brandonisio, A. (2005): Effect of Water, Soil Temperatures, and Exposure Times on the Survival of the Sugar Beet Cyst Nematode: Heterodera schachtii. Phytopathol., 95 (4): 339 - 344. DOI: 10.1094/PHYTO-95-0339

DAVEY, C. B. (1996): Nursery soil management - organic amendments. In: LANDIS, T. D., DouTH, D. B. (Eds), National Proceedings, Forest and Conservation Nursery Associations. General Technical Report PNW-GTR-389: USDA Forest Service PNWRS, pp. 6 - 18

De Bertoldi, M. (2008): Production and utilization of suppressive composts: enviromental, food and health benefit. In: Insam H., Franke-Whittle \& Goberna M. (Eds). Microbes at Work from Wastes to Resource. Pp. 153 - 170. DOI: 10.1007/978-3-642-04043-6_8

Everts, K. L., SARdanelli, S., KRAtochyil, R. J., Armentrout, D. K., Gallagher, L. E. (2006): Root-knot and root lesion nematode suppression by cover crops, poultry litter and poultry litter compost. Plant Dis., 90: 487 - 492. DOI: 10.1094/PD-90-0487

Gamliel, A., Austerweil, M., Kritzman, G. (2000): Non-chemical approach to soilborne pest anagement organic amendments. Crop Prot., 19: 847 - 853. DOI: 10.10 16/S0261-2194(00)00112-5

HU, C, QI, Y. C. (2010): Abundance and diversity of soil nematodes as influenced by different types of organic manure. Helminthologia, 47: 58 - 66. DOI 10.2478/s1168 7-010-0009-8

Ismail, A. E., RawiA, A. E, El-Nagdi, W. M. A. (2006): Effect of different composts, biofertilizers and olive pom- 
ace as soil amendments on Rotylenchulus reniformis, growth and chemical analysis of jasmine Egypt. J. Appl. Sci. Res. 2: 909 - 916

Kimpinski J., Gallant C. E., Henry R., Macleod J. A., SANDERSON J. B., STURZ A. V. (2003): Effect of compost and manure soil amendments on nematode and on yields of potato and barley: a 7-years study. J. Nematol., 35: $289-$ 293

KovÁČIK, P., UHER, A., LoŠÁK, T., TAKÁČ, P. (2008): The effect of quickly fermented pig manure on the broccoli yield parameters and selected soil parameters. Acta Univ. Agric. et Silvitc. Mendel. Brun., 56: $119-124$

KovÁČIK, P., KozÁneK, M., TAKÁČ, P., GallikovÁ, M., VARGA, L. (2010): The effect of pig manure fermented by larvae of house flies on the yield parameters of sunflowers. Acta Univ. Agric. Silvitc. Mendel. Brun., 58: 147 - 154

MiAn, I. H., RodríGUEZ-KÁBANA, R. (1982): Soil amendments with oil cakes and chicken litter for control of $\mathrm{Me}$ loidogyne arenaria. Nematropica, 12: 205 - 220

McSorley, R., GALlaher, R. N. (1995): Effect of yard waste compost on plant parasitic nematode densities in vegetable crops. J. Nematol., 27: 545 - 549

McSORLEY, R., GALLAHER, R. N. (1996): Effect of yard waste compost on nematode densities and maize yield. $J$. Nematol., 28: 655 - 660

McSorley, R., Stansly, P. A., Noling, J. W., Obreza T. A., CONNER J. N. (1997): Impact of soil organic amendments and fumigation on plant parasitic nematodes in a southern Florida vegetable field. Nematropica, 27: 181 $-189$

Mulvaney, R. L. (1996): Nitrogen - inorganic forms. In: SPARKS D.L. (Ed.). Methods of soil analysis . Part 3 Chemical methods. Books series 5. MADISON, WI, U.S.A. Soil Science Society of America. pp. 1123-1189

Navarro, A. F., Cegarra, J., Roig, A., Garcia, D. (1993): Relationship between organic matter and carbon contents of organic wastes. Bioresour. Technol., 44: 203 207

Nico, A. I., JimÉnEZ-DìAZ, R. M., CAstillo, P. (2004): Control of root-knot by composted agro-industrial wastes in potting mixtures. Crop Prot., 23: 581 - 587. DOI: 10.10 16/j.crop.2003.11.005

OKA, Y., YERMIYAHU, U. (2002): Suppressive effects of composts against the root-knot nematode Meloidogyne javanica on tomato. Nematology, 4: 891 - 898. DOI: 10.11 63/156854102321122502

RENČO M., D’ADDABBo T., SASANElli N., PAPAJOVÁ I. (2007): The effect of five compost of different origin on the survival and reproduction of Globodera rostochiensis. Nematology, 9: 537 - 543. DOI: 10.1163/15685410778148 7260

RENČO M., SASANELli N., ŠALAMúN, P. (2009): The effect of two compost soil amendments, based on municipal green and penicillin production wastes, on plant parasitic nematodes. Helminthologia, 46, 3: 190 - 197. DOI: 10.24 78/s11687-009-0035-6

RenČo M., Sasanelli N., D’addabbo T., Papajová I. (2010): Soil nematode community canges associated with compost amendments. Nematology, 12: 681 - 692. DOI: 10.1163/138855409X12584413195491

RiverA, L., AbBAlay, E. (2008): Nematicide Effect of Variuos Organic Soil Amendments on Meloidogyne ethiopica Whitehead, 1968, on Potted Vine Plants. Chil. J. Agric. Res., 68(3): 290 - 296. DOI: 10.4067/S071858392008000300009

Rodríguez-KÁBanA，R., Morgan-Jones, G., Chet, I. (1987): Biological control of nematodes: soil amendments and microbial antagonists. Pl. Soil, 100: 237 - 247. DOI: 10.1007/BF02370944

Rodríguez-Kábana, R., Pinochet, J., CAlvet, C. (1992): Olive pomace for control of plant-parasitic nematodes. Nematropica, 22: $149-158$

Rodríguez-KÁBAna, R., Estaun, V., PinOchet, J., MARFÀ, O. (1995): Mixtures of olive pomace with different nitrogen sources for the control of Meloidogyne spp. on tomato. J. Nematol., 27(4S): 575 - 584

SABOVÁ M., VALOCKÁ B. (1980). Parasitic nematodes of cereals in Slovak Republic. Agricultural, 26: 278 - 258

SAsanelli, N., D’AddabBo, T., Convertini, G., Ferri, D. (2002): Soil Phytoparasitic Nematodes Suppression and Changes of Chemical Properties Determined by Waste Residues from Olive Oil Extraction. In Proceedings of $12^{\text {th }}$ ISCO Conference, May 26 - 31, Beijing China. Vol. III: $588-592$

SAsanelli, N., Ferri, D., Convertini, G., D’AdDabbo, T. (2006): Nematicidal and agronomical effects of composted olive pomace amendments. Proceedings of the $12^{\text {th }}$ Congress of the Phytopatological Union. 11 - 15 June. Rhodos Island, Greece, Pp. 565 - 567

SAsanelli, N., Ciccarese, F., Papajova, I. (2008): Aphanocladium album by sub-irrigation in the control of Pyrenochaeta lycopersici and Meloidogyne incognita on tomato in a plastic-house. Helminthologia, 45: $137-142$. DOI: $10.2478 / \mathrm{s} 11687-008-0027-y$

Sasanelli, N., Anton, A., TAKÁcs, T., D’ADDabBo, T., BIRÓ, I., MALOV, X (2009): Influence of arbuscular mycorrhizal fungi on the nematicidal properties of leaf extracts of Thymus vulgaris L. Helminthologia, 46: 230 - 240. DOI 10.2478/s11687-009-0043-6

SCHLANG, J. (1993): Controlling ematodes by composting. Deutsche Landwirtschafts-Gesselschaft Mitteilungel Agrar Inform. 108: 30 - 31

STN SlovaK TECHNICAL NORMS 465735 (1991): Industrial composts

Sundararaju P., Mustaffa, M. M., Kumar, V., CANNAYANe I., TANUJA PRIYA, B. (2002): Effect of organic farming on plant-parasitic nematodes infesting banana cv. Karpuravalli, Curr. Nematol., 13: $39-43$

SzCZECH, M., RoNDOMANSKI, W., BRZESKI, M. W., SMOLINSKA, U., KotowsKi, J. F. (1993): Suppressive effect of a commercial earthworm compost on some root infecting pathogens of cabbage and tomato. Biol. Agricul. Hort., 10: 47 - 52

TESTER, C. F. (1990): Organic amendment effects on physical and chemical properties of a sandy soil. Soil Sci. Soc. Am. J., 65: 827 - 831. DOI: 10.2136/sssaj1990.543827x 
VAnNACCI, G., Gullino, M. L. (2000): Use of biological agents against soil borne pathogens: Results and limitations. Acta Horticulturae, 532: $79-87$

ZHAO, Y. X., LIU, Q. Z., CAO, Z. P., WU, W. L. (2003):

Effect of fertilizer on population dynamics of plant para-

RECEIVED NOVEMBER 25, 2010 sitic nematodes. Plant Prot., 29: 19 - 22. DOI: CNKI:SU N:ZWBH.0.2003-06-006

ZUNKE, U., EISENBACK, J. D. (1998): Morphology and ultrastructure. In: SHARMA S.B. (Ed.). The Cyst nematodes. Kluver Academy Publisher, London U.K., Pp. 31 - 56 